\title{
A COMPARATIVE STUDY OF RED CELL VOLUMES IN HUMAN SUBJECTS WITH RADIOACTIVE PHOSPHORUS TAGGED RED CELLS AND T-1824 DYE 1, 2
}

\author{
By HERMAN M. NACHMAN, G. WATSON JAMES, III, 3 JOHN W. MOORE, AND \\ EVERETT IDRIS EVANS WITH THE TECHNICAL ASSISTANCE OF \\ EVELYN HAYES AND THOMAS LARGEN
}

(From the Department of Surgery, Surgical Research Laboratories, and the Department of Physics, Medical College of Virginia, Richmond)

(Received for publication August 17, 1949)

In recent years, total blood volume and red cell volume have become an important measurement in experimental and clinical investigation of the hemodynamics of shock, burns, hemorrhage and fluid replacement.

The vital red method of Keith, Rowntree and Geraghty (1) introduced in 1915 was utilized by Robertson and Bock (2) during World War I to study blood volume in wounded soldiers. In recent years the Gibson and Evans (3) modification of Gregersen's T-1824 dye method has been widely used to study traumatic shock clinically $(4,5)$.

The measurement of the red cell volume by T-1824 plasma dye is determined indirectly from the centrifuge hematocrit value. It is generally agreed by most investigators that this value overestimates the red cell volume. Chapin and Ross (6) found a positive error of $8.5 \%$ in the centrifuge hematocrit. Gregersen and Schiro (7) showed that an average of $4.2 \%$ of dye and plasma remained in the erythrocyte mass when blood samples containing T-1824 or Brilliant Vital Red were centrifuged. Furthermore, it has been shown that the hematocrit of a peripheral vessel of the dog does not reflect the hematocrit of all of the vessels of the body (8).

The results of whole blood transfusions in the treatment of shock, burns, chronic infections and other surgical problems have stimulated interest in the total red cell volume as well as in the total blood volume. Consequently, an accurate method

\footnotetext{
1 Supported by grants from the Office of Naval $\mathrm{Re}$ search and the Research and Development Board, Office of the Surgeon General, U. S. Army.

2 Presented at the Clinical Congress of the American College of Surgeons in Los Angeles, California, October 21, 1948.

Research Fellow, Department of Medicine, Medical College of Virginia.
}

for measuring total red cell volume has been the objective of many investigators in the past few years.

The availability of radioactive isotopes opened a new approach to the study of red cell volume. Radioactive phosphorus $\left(\mathrm{P}^{32}\right)$ and two radioisotopes of iron $\left(\mathrm{Fe}^{55}\right.$ and $\mathrm{Fe}^{59}$ ) have received the widest application in this type of investigation.

In 1940 Hahn et al. (9) first described a method of determining red cell volume by means of radioactive iron tagged red cells. They found that radioactive iron administered orally to dogs became incorporated into their erythrocytes and that the "tag" remained as long as the cell existed intact. Tagged red cells obtained by this technique were used to measure the red cell volume of another animal by the isotope dilution method. Shortly thereafter, the same workers did a comparative study of the red cell and plasma volumes by the radioiron and dye method in dogs (10). Elaborating on the original technique of Hahn, Gibson et al. $(11,12)$ and Meneely et al. (13) used radioiron tagged red cells to determine the red cell volume in humans.

In 1940 Hahn and Hevesy (14) obtained $\mathrm{P}^{32}$ tagged red cells by injecting this isotope in a rabbit and allowing the animal to incorporate this material into its red cells. These tagged red cells were then used to measure the red cell volume of a second rabbit by the isotope dilution technique. Hevesy and Zerahn (15), a short time later, showed that red cells could be tagged with $\mathrm{P}^{32}$ in vitro after two hours incubation at $37^{\circ} \mathrm{C}$. Hevesy (16) demonstrated that inorganic $P^{82}$ upon entering the red cells is rapidly incorporated into organic phosphate compounds and that the loss of these compounds from the red cells is negligible at the end of one hour. Nylin (17-20) has utilized $\mathrm{P}^{32}$ tagged red cells to study blood volume, 
TABLE I

Composite data of 40 plasma and red cell volumes done simultaneously

\begin{tabular}{|c|c|c|c|c|c|c|c|c|c|c|c|c|c|}
\hline $\begin{array}{l}\text { Exp. } \\
\text { no. }\end{array}$ & Date & Age & 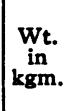 & Clinical diagnosis & $\begin{array}{c}\text { Plasma } \\
\text { volume } \\
\text { by } \\
T-1824\end{array}$ & $\begin{array}{c}\text { Av. } \\
\text { venous } \\
\text { ht. }\end{array}$ & $\begin{array}{c}\text { Blood } \\
\text { volume } \\
\text { by } \\
T-1824\end{array}$ & $\begin{array}{l}\text { R.C.V.V. } \\
\text { T-1824 }\end{array}$ & R.C.V. & $\begin{array}{c}\text { Blood } \\
\text { vol. } \\
\text { P.V. } \\
\text { R.C.V. } \\
\text { P.iz }\end{array}$ & 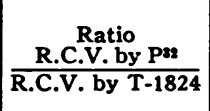 & $\begin{array}{c}\text { Body } \\
\text { ht. }\end{array}$ & $\begin{array}{l}\text { Ratio } \\
\text { Body ht. }\end{array}$ \\
\hline \multirow[t]{2}{*}{$\begin{array}{l}10 \\
11 \\
12 \\
13 \\
14 \\
15 \\
16 \\
17 \\
18 \\
19 \\
21 \\
22 \\
23 \\
24 \\
25 \\
26 \\
27 \\
29 \\
30 \\
31 \\
33 \\
35 \\
36 \\
37 \\
38 \\
39 \\
41 \\
42 \\
43 \\
44 \\
45 \\
46 \\
47 \\
48 \\
49 \\
50 \\
51 \\
52 \\
53 \\
54\end{array}$} & \multirow[t]{2}{*}{$\begin{array}{l}5 / 26 / 48 \\
5 / 28 / 48 \\
5 / 31 / 48 \\
6 / 2 / 48 \\
6 / 4 / 48 \\
6 / 7 / 48 \\
6 / 9 / 48 \\
6 / 10 / 48 \\
6 / 14 / 48 \\
6 / 15 / 48 \\
6 / 18 / 48 \\
6 / 23 / 48 \\
6 / 24 / 48 \\
6 / 28 / 48 \\
7 / 1 / 48 \\
7 / 2 / 48 \\
7 / 6 / 48 \\
7 / 13 / 48 \\
7 / 14 / 48 \\
7 / 16 / 48 \\
7 / 21 / 48 \\
7 / 26 / 48 \\
7 / 27 / 48 \\
7 / 28 / 48 \\
7 / 29 / 48 \\
7 / 30 / 48 \\
8 / 3 / 48 \\
8 / 4 / 48 \\
8 / 5 / 48 \\
8 / 6 / 48 \\
8 / 10 / 48 \\
8 / 11 / 48 \\
8 / 12 / 48 \\
8 / 12 / 48 \\
8 / 13 / 48 \\
8 / 17 / 48 \\
8 / 18 / 48 \\
8 / 18 / 48 \\
8 / 19 / 48 \\
8 / 19 / 48 \\
\end{array}$} & \multirow[t]{2}{*}{$\begin{array}{l}38 \\
58 \\
18 \\
37 \\
67 \\
30 \\
56 \\
67 \\
34 \\
36 \\
68 \\
34 \\
17 \\
47 \\
18 \\
28 \\
47 \\
20 \\
20 \\
26 \\
64 \\
16 \\
30 \\
37 \\
60 \\
37 \\
18 \\
64 \\
42 \\
25 \\
78 \\
29 \\
42 \\
48 \\
40 \\
65 \\
25 \\
24 \\
38 \\
20\end{array}$} & \multirow[t]{2}{*}{\begin{tabular}{|l|}
72.6 \\
57.3 \\
55.9 \\
68.2 \\
54.6 \\
81.5 \\
70.5 \\
69.1 \\
72.7 \\
54.6 \\
63.6 \\
53.6 \\
57.7 \\
45.4 \\
63.0 \\
69.7 \\
42.0 \\
62.7 \\
63.2 \\
81.8 \\
46.8 \\
61.1 \\
67.1 \\
67.3 \\
65.0 \\
58.0 \\
58.0 \\
55.8 \\
91.5 \\
68.8 \\
49.3 \\
75.9 \\
55.8 \\
51.0 \\
72.7 \\
70.5 \\
63.6 \\
70.0 \\
63.5 \\
55.7
\end{tabular}} & \multirow[t]{2}{*}{$\begin{array}{l}\text { Post-op. appendectomy } \\
\text { Post-op. herniorraphy } \\
\text { Post-op. appendectomy } \\
\text { Bilateral ing. hernia } \\
\text { Infected wrist } \\
\text { Post-op. appendectomy } \\
\text { Post-op. appendectomy } \\
\text { Diabetic ulcer of toe } \\
\text { Stab wound-pneumothorax } \\
\text { Post-op. herniorraphy } \\
\text { Fecal fistula } \\
\text { Post-op. herniorraphy } \\
\text { Post-op. herniorraphy } \\
\text { Postpneumonic empyema } \\
\text { Lacerated rectum } \\
\text { Post-op. appendectomy } \\
\text { Postpneumonic empyema } \\
\text { Post-op. appendectomy } \\
\text { Post-op. appendectomy } \\
\text { Osteo of hip } \\
\text { Post-op. exploratory lap. } \\
\text { Post-op. appendectomy } \\
\text { Gun shot wound of chest } \\
\text { Ischio-rectal abscess } \\
\text { Buerger's disease } \\
\text { Diabetes; inf. of foot } \\
\text { Post-op. appendectomy } \\
\text { Squamous ca. of mouth } \\
\text { Post-op. hysterectomy } \\
\text { Post-op. herniorraphy } \\
\text { Ca. of stomach } \\
\text { Cellulitis of foot } \\
\text { Inguinal hernia } \\
\text { Osteo of mandible } \\
\text { Fractured hip } \\
\text { Ca. of colon } \\
\text { Post-op. appendectomy } \\
\text { Infected hip } \\
\text { Fractured ribs } \\
\text { Renal calculus }\end{array}$} & $\begin{array}{l}3085 \\
3330 \\
2975 \\
3290 \\
2862 \\
4940 \\
2658 \\
2615 \\
2597 \\
3018 \\
1675 \\
2800 \\
2700 \\
2390 \\
2795 \\
2772 \\
2418 \\
2361 \\
3245 \\
2923 \\
2565 \\
2401 \\
2634 \\
2776 \\
2345 \\
3228 \\
2722 \\
3170 \\
2492 \\
2690 \\
2619 \\
2717 \\
2146 \\
2685 \\
3228 \\
3569 \\
2934 \\
3123 \\
2394 \\
2571\end{array}$ & $\begin{array}{l}48.2 \\
40.9 \\
40.3 \\
47.9 \\
43.0 \\
40.1 \\
45.3 \\
40.2 \\
49.1 \\
42.8 \\
61.5 \\
40.1 \\
49.4 \\
26.6 \\
45.7 \\
49.6 \\
28.6 \\
47.5 \\
45.6 \\
49.2 \\
51.0 \\
50.1 \\
42.3 \\
49.4 \\
46.8 \\
37.1 \\
49.6 \\
44.2 \\
44.4 \\
48.8 \\
40.9 \\
47.2 \\
46.6 \\
34.9 \\
43.5 \\
41.6 \\
48.5 \\
47.1 \\
51.0 \\
45.6\end{array}$ & $\begin{array}{l}\mathbf{5 9 6 0} \\
5577 \\
5440 \\
\mathbf{6 3 1 9} \\
5002 \\
\mathbf{8 2 5 0} \\
\mathbf{4 8 5 9} \\
\mathbf{4 3 7 9} \\
\mathbf{5 1 0 0} \\
\mathbf{5 2 7 0} \\
\mathbf{4 3 5 0} \\
\mathbf{4 6 7 0} \\
\mathbf{5 3 3 0} \\
\mathbf{3 3 0 0} \\
\mathbf{5 1 4 3} \\
\mathbf{5 5 0 2} \\
\mathbf{3 3 8 5} \\
\mathbf{4 4 8 6} \\
\mathbf{5 9 6 0} \\
\mathbf{5 7 5 0} \\
\mathbf{5 2 3 8} \\
\mathbf{4 8 0 2} \\
\mathbf{4 5 6 2} \\
\mathbf{5 4 8 0} \\
\mathbf{4 4 0 9} \\
\mathbf{5 1 2 9} \\
\mathbf{5 4 0 5} \\
\mathbf{5 6 8 1} \\
\mathbf{4 4 8 3} \\
\mathbf{5 2 5 6} \\
4431 \\
5150 \\
\mathbf{4 0 2 2} \\
\mathbf{4 1 2 6} \\
\mathbf{5 7 1 0} \\
\mathbf{6 1 0 3} \\
\mathbf{5 6 9 8} \\
\mathbf{5 9 0 6} \\
\mathbf{4 8 8 4} \\
\mathbf{4 7 2 3}\end{array}$ & $\begin{array}{r}2875 \\
2247 \\
2465 \\
3029 \\
2140 \\
3310 \\
2201 \\
1764 \\
2503 \\
2252 \\
2675 \\
1910 \\
2630 \\
910 \\
2348 \\
2730 \\
967 \\
2125 \\
2715 \\
2827 \\
2673 \\
2401 \\
1928 \\
2704 \\
2064 \\
1901 \\
2683 \\
2511 \\
1991 \\
2566 \\
1812 \\
2433 \\
1871 \\
1441 \\
2482 \\
2534 \\
2764 \\
2783 \\
2490 \\
2152\end{array}$ & $\begin{array}{r}2004 \\
1720 \\
2089 \\
2965 \\
2008 \\
2378 \\
1563 \\
1450 \\
1755 \\
2115 \\
1540 \\
1885 \\
2050 \\
664 \\
1789 \\
1679 \\
781 \\
1690 \\
1988 \\
2339 \\
1925 \\
2291 \\
1771 \\
2117 \\
1698 \\
1695 \\
2330 \\
2113 \\
1698 \\
2392 \\
1433 \\
1775 \\
1695 \\
1004 \\
1984 \\
2034 \\
2286 \\
1829 \\
1783 \\
1624\end{array}$ & $\begin{array}{l}5089 \\
5050 \\
5064 \\
6255 \\
4870 \\
7318 \\
4221 \\
4065 \\
4352 \\
5133 \\
3215 \\
4685 \\
4750 \\
3054 \\
4584 \\
4451 \\
3199 \\
4051 \\
5233 \\
5262 \\
4490 \\
4692 \\
4405 \\
4893 \\
4043 \\
4923 \\
5052 \\
5283 \\
4190 \\
5082 \\
4052 \\
4492 \\
3841 \\
3689 \\
5212 \\
5603 \\
5220 \\
4952 \\
4177 \\
4195\end{array}$ & $\begin{array}{l}0.697 \\
0.765 \\
0.847 \\
0.978 \\
0.938 \\
0.718 \\
0.710 \\
0.821 \\
0.701 \\
0.939 \\
0.576 \\
0.987 \\
0.779 \\
0.730 \\
0.762 \\
0.615 \\
0.807 \\
0.795 \\
0.732 \\
0.827 \\
0.720 \\
0.954 \\
0.919 \\
0.783 \\
0.823 \\
0.891 \\
0.868 \\
0.841 \\
0.853 \\
0.932 \\
0.791 \\
0.730 \\
0.906 \\
0.697 \\
0.799 \\
0.803 \\
0.827 \\
0.657 \\
0.716 \\
0.755\end{array}$ & $\begin{array}{l}39.3 \\
34.0 \\
41.2 \\
47.4 \\
41.2 \\
32.4 \\
37.0 \\
35.6 \\
40.3 \\
41.2 \\
47.9 \\
40.2 \\
43.2 \\
21.7 \\
39.0 \\
37.7 \\
24.4 \\
41.7 \\
38.0 \\
44.5 \\
42.9 \\
48.8 \\
40.2 \\
43.3 \\
42.0 \\
34.4 \\
46.1 \\
40.0 \\
40.5 \\
47.1 \\
35.4 \\
39.5 \\
44.1 \\
27.2 \\
38.1 \\
36.3 \\
43.8 \\
36.9 \\
42.7 \\
38.7\end{array}$ & $\begin{array}{l}0.815 \\
0.831 \\
1.026 \\
0.989 \\
0.958 \\
0.807 \\
0.816 \\
0.885 \\
0.820 \\
0.963 \\
0.779 \\
1.002 \\
0.875 \\
0.817 \\
0.854 \\
0.760 \\
0.853 \\
0.878 \\
0.834 \\
0.905 \\
0.841 \\
0.974 \\
0.951 \\
0.877 \\
0.897 \\
0.927 \\
0.929 \\
0.905 \\
0.911 \\
0.965 \\
0.866 \\
0.836 \\
0.946 \\
0.779 \\
0.876 \\
0.874 \\
0.903 \\
0.783 \\
0.837 \\
0.849\end{array}$ \\
\hline & & & & & 2811 & 44.8 & 5131 & 2320 & 1848 & 4659 & 0.800 & 39.4 & 0.880 \\
\hline
\end{tabular}

organ volume and a number of other clinical problems.

The present study is a modification of Hevesy's technique for determining total red cell volume with $\mathrm{P}^{32}$ labelled red cells. The objectives have been (1) to develop a simple, rapid, accurate and easily reproducible method for measuring total blood volume by directly determining both plasma and red cell volume, and (2) to compare the results of the $\mathrm{P}^{32}$ and the $\mathrm{T}-1824$ methods.

\section{MATERIAL}

Forty determinations were carried out on 38 subjects taken at random from the surgical services of the Medical College of Virginia Hospitals.4 Thirteen were white males between 18 and 68 years of age; 23 were colored males between 17 and 78 years of age; and two were colored females 47 and 42 years of age. All but three

* We are greatly indebted to Dr. I. A. Bigger, Professor of Surgery, and to the Surgical House Staff for their help in making available clinical material. subjects ${ }^{5}$ were ambulatory. Their clinical diagnoses are shown in Table I.

\section{METHOD}

Approximately $15 \mathrm{cc}$. of blood are drawn from the antecubital vein of the subject and placed into a rubber stoppered vial containing a sterile solution of approximately 0.1 millicurie of radioactive phosphate and $0.1 \mathrm{cc}$. of .068 $\mathrm{W} / \mathrm{V}$ solution of heparin ${ }^{\circ}$ in saline. The $\mathrm{P}^{\mathrm{x}}$ was obtained from Oak Ridge National Laboratory as phosphoric acid $\mathrm{pH} 3.0$. It was originally buffered with 1 part $2.5 \%$ $\mathrm{W} / \mathrm{V}$ sodium citrate solution and 9 parts $M / 15$ Sorensen phosphate buffer solution but this was discontinued when it was found difficult to keep it pyrogen free. The vial is placed in an incubator at $37^{\circ} \mathrm{C}$. and gently rotated every 10-15 minutes for two hours. Levi (21) has shown the distribution coefficient of labelled phosphate ions between corpuscles and plasma of equal weight to be approximately 1.0 at the end of this time.

After two hours incubation, the blood is centrifuged for three minutes at $3000 \mathrm{RPM}$ and the supernatant plasma

5 Experiments No. 21, 31, and 52.

$6.068 \%$ weight to volume heparin. One hundred $\mathrm{mgm}$. of dried heparin in $14.5 \mathrm{cc}$. of saline; $0.05 \mathrm{cc}$. prevents coagulation of $5.0 \mathrm{cc}$. of whole blood. 
TABLE II

Protocol of a typical experiment

Experiment no. 50. August 17, 1948. Subject: S. D. Age 65 . Wt. 70.5 kgm. Diagnosis: Carcinoma of colon

\begin{tabular}{|c|c|c|c|c|c|c|c|c|c|}
\hline \multirow[b]{2}{*}{ Time } & & \multirow[b]{2}{*}{ Procedure } & \multirow[b]{2}{*}{$\begin{array}{c}\text { Sample } \\
\text { no. }\end{array}$} & \multicolumn{4}{|c|}{ Sample data } & \multicolumn{2}{|c|}{ Determinations } \\
\hline & & & & $\begin{array}{l}\text { Whole } \\
\text { blood }\end{array}$ & $\begin{array}{l}\text { cc. } \\
\text { plasma }\end{array}$ & $\begin{array}{l}\text { cc. } \\
\text { red cells }\end{array}$ & Ht. (\%) & $\begin{array}{c}\text { Optical } \\
\text { density } \\
\text { of plasma }\end{array}$ & $\begin{array}{l}\text { Radio- } \\
\text { activity } \\
\text { (C/M of } \\
\text { cells) }\end{array}$ \\
\hline $10: 25$ AM & $15 \mathrm{cc} . \mathrm{bl}$ & d withdrawn & & & & & & & \\
\hline 12:15 PM & Incubati & completed & & & & & & & \\
\hline 12:50 PM & Three sa & e washings completed & & & & & & & \\
\hline 12:55 PM & Control & nple for dye blank & C & 4.7 & 2.7 & 2.0 & 42.6 & & \\
\hline 12:56 PM & 5.0 cc. 0 & 7 T-1824 injected & & & & & & & \\
\hline 12:58 PM & $\begin{array}{l}10.0 \mathrm{cc} . \\
\text { injected. } \\
\text { placed is }\end{array}$ & $\begin{array}{l}\text { tagged cell suspension } \\
\text { Amount not injected } \\
\text { lagath tube }\end{array}$ & CC & $5.25^{*}$ & $3.1^{* *}$ & 2.2 & 42.3 & & 3808 \\
\hline 1:11 PM & Sample & For plasma dye & 1 & 3.98 & 2.29 & 1.69 & 42.5 & 0.382 & 387 \\
\hline 1:19 PM & Sample & activity analyses & 2 & 4.9 & 2.81 & 2.05 & 41.8 & 0.378 & 394 \\
\hline 1:28 PM & Sample & & 3 & 5.1 & 3.0 & 2.1 & 41.2 & 0.373 & 385 \\
\hline 1:43 PM & Sample & & 4 & 5.0 & 2.98 & 2.02 & 40.2 & 0.363 & 396 \\
\hline 1:58 PM & Sample & & 5 & 5.1 & 3.0 & 2.1 & 41.0 & 0.355 & 391 \\
\hline
\end{tabular}

Calculations by T-1824:

Plasma volume $=\frac{500 \times 0.590 \times 4.958}{0.389}=3569 \mathrm{cc}$.

Blood volume $=3569 \times \frac{100}{100-41.6}=6103 \mathrm{cc}$.

Cell volume $=6103-3569=2534$ cc.

* Red cells suspended in saline. ** CC of saline. 1:100 dilution.
Calculations by $\mathbf{P}^{\mathbf{s}}$ :

$\mathrm{RCV}$ in cc. $=\frac{3808 \times 50 \times 4.23}{395}=2034 \mathrm{cc}$.

Difference in RCV by the two methods.

By T-1824 - 2534 cc. 500

By $\mathrm{P}^{x}-2034$ cc. $\quad \frac{500}{2534}=.1973$ or $19.7 \%$.

$\overline{500 \mathrm{cc} .}$ removed with a sterile syringe and needle. The plasma is discarded and an equal volume of sterile iced physiological saline $(0.9 \mathrm{~W} / \mathrm{V}$ sodium cliloride) added to the cells. The erythrocytes are resuspended in the saline, gently rotated and centrifuged again. Three washings, maintaining sterile technique, are done in this manner and the cells finally suspended in a volume of saline approximately equal to the volume of plasma discarded. After anesthetizing the skin with $1 \%$ procaine $\mathrm{HCl}$ solution, an antecubital vein is punctured with a $19 \mathrm{G}$. needle attached to a three-way stopcock. Five cc. of blood are withdrawn to serve as a blank for the plasma volume determination; then, sufficient physiological saline is allowed to run through the needle to be certain that it is securely in the vein. Five cc. of T-1824 dye, followed by $10.0 \mathrm{cc}$. of the tagged cell-saline suspension ${ }^{7}$ are then injected from calibrated syringes. In each case, the syringe is washed three times with saline. At approxi-

I It is estimated that the total body irradiation from a single red cell volume determination is approximately $\mathbf{3 . 0}$ roentgen equivalent physicals (REP). mately 12, 23, 30, 45 and 60 minutes after injection, approximately $5.0 \mathrm{cc}$. of blood are drawn from an antecubital vein of the opposite arm without stasis and placed into a $6.0 \mathrm{cc}$. Magath centrifuge tube containing $0.05 \mathrm{cc}$. of $0.068 \% \mathrm{~W} / \mathrm{V}$ heparin in saline which has been dried by heating in an oven. The remainder of the tagged cellsaline suspension not injected is placed in a similar tube and denoted as the control cells. All tubes are centrifuged at 3000 RPM for 45 minutes in a size 2 International centrifuge equipped with a No. 240 head, the distance from the axis of the centrifuge to the bottom of the cup being $20.0 \mathrm{~cm}$.

After determining the hematocrit (not including the buffy coat) the supernatant plasma is removed and the concentration of dye measured on a Coleman Junior Spectrophotometer set at $620 \mathrm{~m} \mu$. To each Magath tube is added an amount of $0.1 \% \mathrm{~W} / \mathrm{V}$ sodium carbonate solution exactly equal in volume in cubic centimeters to the volume of packed cells; thus giving a 1:1 dilution of red cells. These are shaken vigorously until all cells are hemolyzed.

The control cells are further diluted as follows: $0.1 \mathrm{cc}$ 
of the $1: 1$ dilution is made up to $5.0 \mathrm{cc}$. with distilled water, giving a $1: 100$ dilution. Then the radioactivity of the control cells and the other cells is determined in the following manner: Exactly $0.1 \mathrm{cc}$. of hemolyzed cell solution from each tube is carefully pipetted onto a copper planchet $1^{\prime \prime}$ in diameter and evenly spread by adding one drop of $10 \%$ aerosol OT 8 solution. These are dried at room temperature for approximately 30 minutes. The same pipette is used throughout but is carefully washed and dried between samples.

A Geiger tube and scaling circuit are used to measure the radioactivity of each sample. The Geiger tubes are of the self-quenching variety, have overall dimension of $3 \% y^{\prime \prime} \times 11 / 2$ " diameter and have mica windows ranging from $2.5-3.5 \mathrm{mgm} . / \mathrm{cm}^{2}$. These are shielded by $2^{\prime \prime}$ of lead and their background counts range from 25-35 counts per minute. They are standardized at regular intervals to determine changes in plateau and counting efficiency. The sample to window distance is $2 \mathrm{~mm}$. and the overall geometric reproducibility is claimed by the manufacturer to be on the order of $0.1 \%$. 4096 counts are totaled for each sample and the result expressed in terms of counts per minute.

\section{CALCULATION OF RED CELL VOLUME}

From the dilutions of the red cells and the radioactivity analyses the red cell volume is calculated as follows:

(1) RCV in cc.

$$
=\frac{\mathrm{C} / \mathrm{M} / \mathrm{cc} .^{\circ} \text { injected } \times \text { cc. of red cells injected }}{\mathrm{C} / \mathrm{M} / \mathrm{cc} . \text { recovered from subject }}
$$

(2) $\mathrm{C} / \mathrm{M} / \mathrm{cc}$. injected $=\mathrm{C} / \mathrm{M} / 0.1$ cc. $\times 10 \times 100$

(3) $\mathrm{C} / \mathrm{M} / \mathrm{cc}$. recovered $=\mathrm{C} / \mathrm{M} / 0.1 \mathrm{cc} . \times 10 \times 2$

(4) cc. of cell injected $=$ cc. of saline suspension $X$ hematocrit

Substituting in (1) therefore

$\mathrm{RCV}$ in cc.

$=\frac{\mathrm{C} / \mathrm{M} / 0.1 \text { cc. } \times 10 \times 100 \times \text { cc. of red cells injected }}{\mathrm{C} / \mathrm{M} / 0.1 \mathrm{cc} . \times 10 \times 2}$

$\mathrm{RCV}$ in cc. $\mathrm{C} / \mathrm{M}$ of control sample $\times 50.0 \times \mathrm{cc}$. of cells injected $\mathrm{C} / \mathrm{M}$ test cells Irom subject

Table II is a protocol of a typical experiment.

To determine the technical error in pipetting and counting, 10 samples from a tube of hemolyzed cells were prepared and each sample counted 10 times. The coefficient of variation ${ }^{10}$ ranged from a minimum of $0.36 \%$ to a maximum of $3.2 \%$ with an average for the 100 determinations of $2.2 \%$.

\section{RESULTS}

The tabulated results of the 40 determinations are shown in Table I. The T-1824 dye method

8 Dioctyl sodium sulfosuccinate.

- $\mathrm{C} / \mathrm{M} / \mathrm{cc} .=$ counts per minute per cubic centimeter of red cells.

${ }^{10}$ Coefficient of variation $=\frac{S \times 100}{M}$. Coefficient of variation denotes the standard deviation as a percentage of the mean. $\mathrm{N}$ has already been taken into consideration in determining $\mathbf{S}$ (standard deviation). gave a mean red cell volume of $2320 \pm 79 \mathrm{cc}$; with the $\mathrm{P}^{32}$ method the mean red cell volume was 1850 $\pm 66 \mathrm{cc}$. These two mean values are significantly different $(d=470 \pm 102 \mathrm{cc}$., $t=4.6, P \angle .01)$. In every case, the red cell volume as determined by the $\mathrm{P}^{\mathbf{3 2}}$ method was less than the comparable value obtained with T-1824 dye. The table shows the ratio of the $R C V$ by $P^{32}$ to the $R C V$ by $T-1824$ for each case. The mean value obtained from these 40 ratios was $0.800 \pm 0.153$. None of the individual ratios fell outside the range of the mean ratio plus or minus two and a half times its standard error.

We assume the expression $\frac{R C V \text { by } \mathrm{P}^{32}}{\mathrm{PV}+\mathrm{RCV} \text { by } \mathrm{P}^{32}}$ to be the relationship of red cells to plasma in the entire body (Body ht.) The average body hematocrit of the entire series was 39.4 while the average venous hematocrit was 44.8 . The average venous hematocrit is found by averaging the hematocrit of the six blood samples taken without a tourniquet in the course of the experiment. No. correction factor is applied for the occluded plasma.

\section{DISCUSSION}

Determination of the red cell volume by means of tagged erythrocytes is based upon the following assumptions: (1) the tag remains essentially intact with the red cell for the time of the experiment, (2) the physical principle of dilution of tagged particulate matter is accurate for measuring changes in volume of similar particulate matter, and (3) all of the tagged cells become completely mixed with the untagged cells of the subject.

That the radioactive tag remains essentially intact in the red cell for longer than one hour has been shown conclusively by $\mathrm{Nylin}$ (22) and confirmed by us. Figure 1 illustrates a typical experiment and shows the activity of the red cells as a function of time. Furthermore, radioactive analyses of the supernatant plasma of samples taken up to one hour after injection do not show sufficient activity to indicate any significant loss of activity from the tagged cells to the plasma. Aliquots of the plasma counted $50-60 \mathrm{C} / \mathrm{M}$ while our background was $25-35 \mathrm{C} / \mathrm{M}$. The ratio of the counting rate of the cells to background was $10: 1$ to $15: 1$.

The validity of the second assumption was tested by an in vitro experiment designed to measure the 


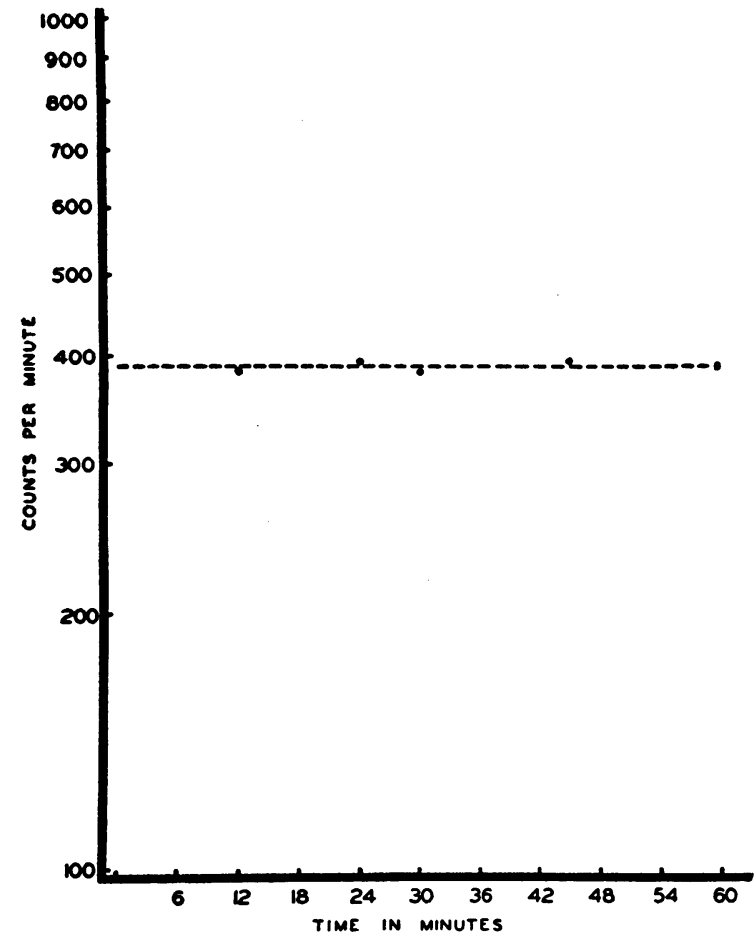

Fig. 1. Counts per Minute Contained in Red Cells As a Function of Time

red cell volume of a definite quantity of blood. Tagged cells were introduced into a measured quantity of blood and thoroughly mixed by gentle rotation. At 12 minute intervals up to one hour, samples were poured off into Magath centrifuge tubes. The red cell volume by the isotope dilution technique agreed within $4 \%$ of the volume determined from the hematocrit corrected for the occluded plasma by Gregersen's factor of 0.96 (23) (Table III).

The third assumption is difficult to prove, but the constant activity of the red cells up to one hour after injection strongly suggests that it is valid.

It has been stated the red cell volume as deter-

TABLE III

Values of in vitro experiment to measure known volume of red cells

\begin{tabular}{c|c|c|c|c|c}
\hline \hline $\begin{array}{c}\text { Deter- } \\
\text { mination } \\
\text { no. }\end{array}$ & $\begin{array}{c}\text { Volume of } \\
\text { whole } \\
\text { blood }\end{array}$ & $\begin{array}{c}\text { Hema- } \\
\text { tocrit } \\
\text { in } \\
\%^{*}\end{array}$ & $\begin{array}{c}\text { Calculated } \\
\text { volume of } \\
\text { red cells } \\
\text { (ht. } \times 0.96)\end{array}$ & $\begin{array}{c}\text { Volume } \\
\text { of red } \\
\text { cells by } \\
\text { Pas }^{20}\end{array}$ & $\begin{array}{c}\text { Per rent } \\
\text { differ- } \\
\text { ence }\end{array}$ \\
\hline 1 & $1000 \mathrm{cc}$ & 38.6 & 370 & 389 & +4.1 \\
2 & $1000 \mathrm{cc}$. & 41.1 & 395 & 384 & -2.5 \\
\hline
\end{tabular}

* Average of five determinations. mined by the isotope dilution technique is independent of the arterial or venous hematocrit (11). Although this statement is factually correct, the hematocrit does enter into the calculation of the red cell volume when the volume of tagged red cells injected is calculated. The volume of red cells injected is thus overestimated since no account is taken of the occluded saline when the hematocrit of this suspension is determined.

Correction factors have been proposed for occluded plasma (Gregersen's 0.96 ), but a correction factor for occluded saline has not been determined. Experiments are planned to determine this variable.

A similar error is introduced when the volume of red cells is hemolyzed with an exact volume of $0.1 \%$ sodium carbonate solution. However, since both control and test cells are treated alike this error cancels itself.

We assume that the packing factor of the tagged cell-saline suspension remains constant in each experiment. It is obvious that application of a correction factor here would make the red cell volume by the isotope dilution technique even lower than presented values.

Similar studies of simultaneously determining red cell volume with tagged cells and plasma volume with T-1824 have been conducted by Gibson et al. (11) and Meneely and his group (13) using radioactive iron. In a series of 40 normal males, Gibson found an average ratio of red cell volume by radioiron to red cell volume by $\mathrm{T}-1824$ of 0.845 . The standard error of the mean of his series was \pm 0.11 . The average ratio of the body hematocrit to average venous hematocrit for his series was 0.906 . Meneely's study included 28 male patients and revealed an average ratio of red cell volume by radioiron to red cell volume by $\mathrm{T}-1824$ of 0.809 , with the standard error of the mean being \pm 0.122 . The average ratio of the body hematocrit to average venous hematocrit for his series was 0.887 .

Mutual confirmation of the results of the radioiron and radiophosphorus techniques is suggested by the lack of a significant difference in their mean ratios.

Further evidence confirming the results presented here is found in the recent report of Reeve and Veall (24). These workers using a technique 
similar to ours found the mean ratio of red cell volume by $\mathrm{P}^{32}$

red cell volume by $\mathrm{T}-1824$

to be 0.87 . Hematocrit values in their study were corrected by a factor of 0.95 .

Correction of the hematocrit for trapped plasma was purposely omitted in the basic calculations (Table I), to facilitate a more fundamental comparison of methods. If Gregersen's correction factor $(0.96)$ is applied to the hematocrits in Table $I$, the mean ratio of

$$
\frac{\text { red cell volume by } \mathrm{P}^{32}}{\text { red cell volume by } \mathrm{T}-1824}
$$

is 0.87 .

Mayerson, Lyons et al. (25) report a mean ratio of $\frac{\text { red cell volume by } \mathrm{P}^{\mathbf{3 2}}}{\text { red cell volume by } \mathrm{T}-1824}$ of 0.99 . This unusually high ratio is probably due to (1) dissimilar basic techniques and (2) the use of a hematocrit correction factor of 0.915 (26).

The $\mathrm{P}^{\mathbf{3 2}}$ method as described here is easily done and has many advantages over radioiron. It is necessary to produce a donor of radioactive cells when iron is used, but when $\mathrm{P}^{32}$ is used, the subject's own red cells may be conveniently tagged. Furthermore, the concern of blood type and $\mathrm{Rh}$ compatibility is eliminated. Separated isotopes of radioiron are difficult to produce in either the cyclotron or the chain reacting pile. Some longlife iron is usually present in the most carefully separated isotopes of iron. Concern has been expressed over the use of long-life isotopes such as $\mathrm{Fe}^{55}$ (half-life, four years) in human subjects. The use of $\mathrm{P}^{32}$ (half-life, 14.8 days) eliminates this concern. The preparation of blood samples containing iron for radioactive analysis is a complicated procedure. The red cells are wet ashed and the iron precipitated; the iron must then be redissolved and electrolytically deposited on copper discs in a special apparatus before the activity can be measured. Radioactivity analysis of $\mathrm{P}^{\mathbf{3 2}}$ tagged red cells can be simply carried out on hemolyzed red cells by the method described.

\section{CONCLUSIONS}

1. A comparative study of the red cell and plasma volumes of 38 surgical patients as measured by $\mathrm{P}^{32}$ tagged red cells and T-1824 plasma dye is presented.
2. On the average, the red cell volume as measured with $\mathrm{P}^{32}$ tagged red cells is $20.0 \%$ less than the value obtained with T-1824 plasma dye.

3. This discrepancy is probably due to the difference in the hematocrit of blood in peripheral veins and blood in other vessels of the body and to the intrinsic error of the centrifuge hematocrit.

4. The body hematocrit on the average, is $12.0 \%$ less than the average venous hematocrit.

5. The hematocrit value enters into the calculation of the red cell volume by the isotope dilution techniques and probably results in slight overestimation of the red cell volume.

6. Statistically, results of the present study do not differ significantly from similar studies using radioiron tagged red cells.

7. The advantages of the $P^{32}$ method over the radioiron method are outlined.

\section{BIBLIOGRAPHY}

1. Keith, N. M., Rowntree, L. G., and Geraghty, J. T., A method for determination of plasma and blood volume. Arch. Int. Med., 1915, 16, 547.

2. Robertson, O. H., and Bock, A. V., Blood volume in wounded soldiers. I. Blood volume and related blood changes after hemorrhage. J. Exper. Med., 1919, 29, 139.

3. Gibson, J. G., 2nd, and Evans, W. A., Jr., Clinical studies of the blood volume. I. Clinical application of a method employing the azo dye "Evans Blue" and the spectrophotometer. J. Clin. Invest., 1937, $16,301$.

4. Evans, E. I., Hoover, M. J., James, G. W., III, and Alm, T., Studies on traumatic shock. I. Blood volume changes in traumatic shock. Ann. Surg., 1944, 119, 64.

5. Noble, R. P., and Gregersen, M. I., Blood volume in clinical shock. II. The extent and cause of blood volume reduction in traumatic, hemorrhagic and burn shock. J. Clin. Invest., 1946, 25, 172.

6. Chapin, M. A., and Ross, J. F., The determination of the true cell volume by dye dilution, by protein dilution, and with radioactive iron. The error of the centrifuge hematocrit. Am. J. Physiol., 1942, 137, 447.

7. Gregersen, M. I., and Schiro, H., The behavior of the dye $\mathrm{T}-1824$ with respect to its absorption by red blood cells and its fate in blood undergoing coagulation. Am. J. Physiol., 1938, 121, 284.

8. Gibson, J. G., 2nd, Seligman, A. M., Peacock, W. C., Aub, J. C., Fine, J., and Evans, R. D., The distribution of red cells and plasma in large and minute vessels of the normal dog, determined by radioactive isotopes of iron and iodine. J. Clin. Invest., 1946, $25,848$. 
9. Hahn, P. F., Balfour, W. M., Ross, J. F., Bale, W. F., and Whipple, G. H., Red cell volume circulating and total as determined by radioiron. Science, 1941, 93, 87.

10. Halin, P. F., Ross, J. F., Bale, W. F., Balfour, W. M., and Whipple, G. H., Red cell and plasma volumes (circulating and total) as determined by radioiron and by dye. J. Exper. Med., 1942, 75, 221.

11. Gibson, J. G., 2nd, Peacock, W. C., Seligman, A. M., and Sack, T., Circulating red cell volume measured simultaneously by the radioactive iron and dye methods. J. Clin. Invest., 1946, 25, 838.

12. Gibson, J. G., 2nd, Weiss, S., Evans, R. D., Peacock, W. C., Irvine, J. W., Jr., Good, W. M., and Kip, A. F., The measurement of the circulating red cell volume by means of two radioactive isotopes of iron. J. Clin. Invest., 1946, 25, 616.

13. Meneely, G. R., Wells, E. B., and Hahn, P. F., Application of the radioactive red cell method for determination of blood volume in humans. Am. J. Physiol., 1947, 148, 531.

14. Hahn, L., and Hevesy, G., A method of blood volume determination. Acta physiol. Scandinav., 1940, $1,3$.

15. Hevesy, G., and Zerahn, K., Determination of the red corpuscle content. Ibid, 1942, 4, 376.

16. Hevesy, G., Radioactive Indicators; Their Application in Biochemistry, Animal Physiology, and Pathology. Interscience Publishers, Inc., New York, 1948.

17. Nylin, G., Blood volume determination with radioactive phosphorus. Brit. Heart J., 1945, 7, 81.
18. Nylin, G., Circulatory blood volume of some organs. Am. Heart J., 1947, 34, 174.

19. Nylin, G., The effect of heavy muscular work on the volume of circulating red corpuscles in man. Am. J. Physiol., 1947, 149, 180.

20. Nylin, G., and Blörck, G., Circulatory corpuscle and blood volume in a case of patent ductus arteriosus before and after ligation. Acta med. Scandinav., 1947, 127, 434.

21. Levi, H., The action of honey bee venom on red corpuscles, especially on their ionic permeability. Arkiv Kemi, Mineral. och Geol., 1945, 21A, 1.

22. Nylin, G., Studies on the circulation with the aid of blood corpuscles labelled with radioactive phosphorus compounds. Arkiv Kemi, Mineral. och Geol., 1945, 20A, 1.

23. Gregersen, M. I., A practical method for the determination of blood volume with the dye T-1824. J. Lab. \& Clin. Med., 1944, 29, 1266.

24. Reeve, E. B., and Veall, N., A simplified method for the determination of circulating red cell volume with radioactive phosphorus. J. Physiol., 1949, $108,12$.

25. Mayerson, H. S., Lyons, C., Parson, W., Nieset, $\mathbf{R}$. T., and Trautman, W. V., Jr., Comparison of results of measurement of red blood cell volume by direct and indirect technics. Am. J. Physiol., 1948, $155,232$.

26. Nieset, R. T., Porter, B., Trautman, W. V., Jr., Bell, R. M., Parson, W., Lyons, C., and Mayerson, H. S., Determination of circulating red blood cell volume with radioactive phosphorus. Am. J. Physiol., 1948, 155, 226. 